\title{
The Challenges of Attaining the Millennium Development Goals (MDGs) ${ }^{1}$
}

\author{
M. Larionova
}

Marina Larionova, PhD, Head, Centre for International Institutions Research (CIIR), Russian Presidential Aca- demy of National Economy and Public Administration (RANEPA); Professor, Faculty of World Economy and International Affairs, National Research University Higher School of Economics; 11 Prechistenskaya naberezhnaya, Moscow, 119034, Russian Federation; E-mail: larionova-mv@ranepa.ru

\begin{abstract}
The history of the millennium development goals (MDGs), the achievement of which experienced a major setback with the outbreak of the 2008 global economic and financial crisis, may provide some useful insights on the global partnership for the sustainable development goals (SDGs). There is a vast literature devoted to the MDGs. Most of the analysis is focused on the implementation and progress made toward achieving the MDGs. Fewer authors explore reasons for shortfalls or describe intrinsic limitations to the MDG framework, including limitations in the development, formulation and content of the MDGs themselves.

This article reviews cooperation on the MDGs, exploring the priorities of different stakeholders and the challenges to progress in the broader context of development and global governance. The review focuses on MDG 8, developing a global partnership for development. Added to the MDGs due to Kofi Annan's leadership, MDG 8 helped to attract support from developing countries which viewed the MDGs as reflecting a one-sided deal favouring the interests of rich countries. Inclusion of the goal to reform the international economic system appeased some critics of the international development goals that were put forward by the Organisation for Economic Co-operation and Development (OECD) and taken as the basis for the MDGs. This article argues that despite the endeavour by the United Nations (UN) General Assembly to steer the development of global partnerships, extrinsic barriers such as lack of political will on the part of the key stakeholders, the financial crisis, and vested interests prevented delivery on $M D G$ 8's key target of developing an open, predictable, rule-based, non-discriminatory trading and economic system. Achievement of this goal is necessary in order to create the equitable and inclusive international order demanded by developing countries for decades. Most markedly, a lack of progress on MDG 8's goal of addressing systemic issues of global economic governance became the greatest challenge to achieving the MDGs, and the greatest disappointment. Systemic problems were inherited by the SDGs, the achievement of which requires a truly global partnership able to build a new economic order as a foundation for inclusive and sustainable development.

This review draws on content analysis of General Assembly resolutions and the official records of its 55th to 70 th sessions, documents from the three conferences on financing for development, the crisis summit, reports on MDG results, and public statements and analytical narratives about the MDGs.
\end{abstract}

Key words: millennium development goals (MDGs); a global partnership for development; reform of the international economic system; the UN; global financial and economic crisis; sustainable development goals (SDGs)

For citation: Larionova M. The Challenges of Attaining the Millennium Development Goals (MDGs). International Organisations Research Journal, vol. 15, no 1, pp. 155-176 (in Russian and English). DOI: 10.17323/1996-7845-2020- 01-07.

${ }^{1}$ This research was carried out with the financial support of the Russian Foundation for Basic Research within the framework of a research project entitled "Evolution of Multilateral Development Cooperation Under the Auspices of the United Nations: From Development Decade to Sustainable Development Goals (SDGs)," project no 18-014-00008. 


\section{Introduction}

Five years after the adoption of the sustainable development goals (SDGs), the World Economic Outlook (WEO) projected a decline in growth in 2019 for $70 \%$ of the global economy. Geopolitical tensions, trade disagreements, distorted barriers and crumbling multilateralism put a drag on economic growth, risking a protracted global slowdown [IMF, 2019] and hindering progress toward achieving most of the SDGs. This is not a new story. The history of the millennium development goals (MDGs), the achievement of which experienced a major setback with the outbreak of the 2008 global economic and financial crisis, may provide some useful insights on the global partnership for the sustainable development goals (SDGs). There is a vast literature devoted to the MDGs. Most of the analysis is focused on the implementation and progress made toward achieving the MDGs. Fewer authors explore reasons for shortfalls or describe intrinsic limitations to the MDG framework, including limitations in the development, formulation and content of the MDGs themselves [Fehling, Nelson, Venkatapuram, 2013].

This article reviews cooperation on the MDGs, exploring the priorities of different stakeholders and the challenges to progress in the broader context of development and global governance. It argues that despite the endeavour by the United Nations (UN) General Assembly (GA) to steer the development of global partnerships, extrinsic barriers such as lack of political will on the part of the key stakeholders and the financial crisis suppressed the process. Due to the key stakeholders' vested interests, the international community failed to deliver on MDG 8's key target of developing an open, predictable, rule-based, non-discriminatory trading and economic system. Achievement of this goal is necessary in order to create the equitable and inclusive international order demanded by developing countries for decades. ${ }^{2}$ This review draws on content analysis of General Assembly resolutions and official records from its 55th to 70th sessions, documents from the three conferences on financing for development, the crisis summit [UN, 2009b], reports on MDG results, and public statements and analytical narratives about the MDGs.

\section{Setting the MDGs}

The Millennium Declaration heralded at the GA's 55th session was proceeded by complex preparatory processes in which multiple actors were involved, advancing their competing and sometimes contradictory priorities. The frantic negotiations on the MDGs continued after the Millennium summit. The Development Assistance Committee (DAC) of the Organisation for Economic Co-operation and Development (OECD), the World Bank and the International Monetary Fund (IMF) wanted the international development goals (IDGs) proposed by the OECD in its "Shaping the 21st Century" document [1996] to be the MDGs [Hulme, 2009, pp. 33-43]. The UN was prepared to compromise if the international financial institutions (IFIs) would take responsibility for support of the poverty reduction strategies of the developing countries with a clear division of labour between UN agencies and the IFIs. The IDGs became the basis for the MDGs, which were agreed to as a result of tough consultations and presented in the secretary-general's first report on the Millennium Declaration. "The proposed formulation of the eight goals, 18 targets and more than 40 indicators" included a significant addition - Goal 8, "Developing a Global Partnership for Development" [UN, 2001a, p. 55].

${ }^{2}$ The Group of $77(\mathrm{G} 77)$ initiative on global negotiations relating to international economic cooperation for development was approved at the 34th session of the GA [UN, 1979]. It sought to establish a new economic order, but encountered opposition from the western states and became one of the landmark failures of the third and fourth development decades (for a full account see M. Larionova and E. Safonkina [2018]). 
As Aldo Caliari pointed out, "Kofi Annan's leadership seems to be the reason for the addition of a MDG 8, which was likely a necessary move to attract support from developing countries. Being born from a DAC project, the Goals were viewed with suspicion by developing countries as being a one-sided deal favoring the interests of rich countries ... A goal to reform the international economic system may have been seen as a way to appease criticisms of the International Development Goals endorsed in earlier publications. Yet, the language and further, the targets, ultimately employed to crystalize those aspirations were far from a concession to globalization critics" [2013, p. 6]. Indeed, it can be traced to the "We the Peoples" report prepared by the office of the secretary-general for the Millennium summit. The inclusion of MDG 8 helped to gain support for the framework. Though there was much criticism of the closed nature of the genesis of the MDGs, they were hailed by many for their simplicity, concise and outcomebased targets, communicability, pragmatism and catalytic effect [Landford, 2016, pp. 169-70].

The MDGs were endorsed at the first International Conference on Financing for Development, held in Monterrey in March 2002. The Monterrey Consensus defined priorities (leading actions) aimed at addressing the challenges to financing for development and to achieving poverty eradication, sustained economic growth and sustainable development [UN, 2002g]. The MDGs became a reference point for development cooperation among UN members, though the world's greatest power, the U.S., confirmed the MDGs only in 2005. As David Hulme noted, President George W. Bush and his administration stated "that all their decisions were based purely on the US national interest and made this point forcefully by refusing to collaborate in international processes to curb climate change... They were highly suspicious of the UN, seeing it as an organisation which was probably anti-American" [2009, p. 42]. This philosophy is also professed by the current administration of President Trump.

The MDGs and the Monterrey Consensus set forth a new phase in the UN's narrative of development cooperation and its continued engagement with the Bretton Woods institutions, the World Trade Organization (WTO), national parliaments, civil society and the private sector in pursuit of inclusive and sustainable economic development. The MDGs helped to advance cooperation on eradicating extreme poverty and hunger (MDG 1), achieving universal primary education (MDG 2), eliminating gender disparity in education (MDG 3), reducing child mortality (MDG 4), improving maternal health (MDG 5), combating HIV/AIDS, malaria and other diseases (MDG 6), ensuring environmental sustainability (MDG 7) and promoting a global partnership for development (MDG 8). Though progress was uneven, it was undoubted and confirmed by hard data [UN, 2015c]. The GA advanced the progress. Over 15 years the secretary-general and the GA persevered in maintaining the momentum for cooperation, pushing for concerted global, regional, national and local efforts, although with different degrees of success.

\section{Advancing the MDGs}

\section{Poverty Eradication}

Cooperation on poverty eradication was boosted by the MDGs, and progress on implementation of the United Nations Decade for the Eradication of Poverty was reviewed at each session. Calling upon "all countries to formulate and implement outcome-oriented national strategies and programmes, setting time-bound targets for poverty reduction, including the target of halving, by 2015, the proportion of people living in extreme poverty" [Ibid., 2002a, Para. 5], the resolutions on eradication of poverty covered a comprehensive set of targets for international cooperation. 
Emphasizing the importance of achieving the target of $0.7 \%$ of the developed countries' gross national product (GNP) allocation for overall official development assistance (ODA), and allocating, on average, $20 \%$ of ODA and $20 \%$ of the developing countries' national budgets to basic social programmes, the GA sought to stimulate a global response, promote global economic governance, and contribute to poverty eradication through specific initiatives such as the establishment of the World Solidarity Fund to eradicate poverty and promote social and human development [UN, 2004a, Para. 27-9]. The fund, proposed by the World Summit on Sustainable Development, was established by the GA's decision at the 58th session. However, the donors were reluctant to create new funding mechanisms. By the end of the UN's First Decade for the Eradication of Poverty it was still not operationalized. It gradually lost prominence in the resolutions and subsequently gave way to a more general call to "strengthen United Nations funding for the eradication of poverty through voluntary contributions to existing poverty-related system-wide funds" [Ibid., 2014, Para. 17].

MDG 1 became one of the most advanced among the MDGs. By 2015, the number of people living in extreme poverty and hunger was estimated to have declined by more than $50 \%$. The global employment-to-working population ratio fell only by $2 \%$, from $62 \%$ in 1990 to $60 \%$ in 2015 [Ibid., 2015c, pp. 14, 17 ] Given that many experts consider that "it is close to impossible to assess the impact of the MDGs on poverty reduction" and that "statistics have been abused to fabricate evidence of success" [Kvangraven, Reddy, 2015, p. 21], assessments of the GA's contribution toward attaining this goal would be even less plausible. Nevertheless, the GA should be credited for pushing poverty to the heart of development cooperation and seeking to mobilize, coordinate and hold accountable the numerous stakeholders in the process, including UN agencies, the multilateral development banks, the donors, the developing countries' national governments, business and civil society.

\section{Universal Primary Education and Elimination of Gender Disparity}

The United Nations Literacy Decade: Education for All (EFA) [UN, 2002b] (1 January 2003 -1 January 2013) provided support to the international EFA initiative as well as two out of the six collective commitments of the Dakar Framework for Action [Ibid., 2000a] adopted at the World Education Forum in 2000. In 2002 the GA approved an international plan of action for the United Nations Literacy Decade prepared by the United Nations Educational, Scientific and Cultural Organization (UNESCO) and reviewed its progress every two years, delegating to UNESCO a coordinating role in stimulating and catalyzing the activities [Ibid., 2002b, Para. 8 ].

Progress on the two education MDGs was mixed. In the 2015 EFA Global Monitoring Report, the primary school net enrolment ratio was estimated to have reached $93 \%$ in 2015 . Between 1999 and 2012 the number of countries with fewer than 90 girls enrolled in primary school for every 100 boys fell from 33 to 16 . At the primary level, $69 \%$ of the countries with data were expected to have reached gender parity by 2015. Progress was slower in secondary education, with $48 \%$ projected to be at gender parity in 2015 . Despite progress in access, dropout remained an issue [Ibid., 2015d]. It is impossible to estimate if the inclusion of the two EFA commitments into the MDGs, the UN plan of action, and the UNESCO activities made a tangible difference for advancing the goals. The EFA Global Monitoring Report team was critical of UNESCO's role noting that "the formal EFA coordination mechanism, led by UNESCO, did not ensure continuous political commitment and had limited success in engaging other agencies and stakeholders" [Ibid., p. 11]. However, though "the world fell short on the MDG to achieve universal primary school education completion by 2015 ... the rate of progress more than doubled accelerating from 0.62 to 1.35 percentage points per year ... leading to an 
estimated 59 million to 111 million more people completing primary school between 2000 and 2015" [McArthur, Rasmussen, 2017, p. 29]. This was an important achievement and the UN clearly deserves some credit for the outcome.

\section{Reducing Child and Maternal Mortality, Combating HIV/AIDS, Malaria and Tuberculosis}

The three health-related goals were not very prominent on the GA's agenda. It followed up on the implementation of the Declaration of Commitment on HIV/AIDS and proclaimed the period 2001-10 as the Decade to Roll Back Malaria in Developing Countries, Particularly in Africa [UN, 2003b]. It supported the high priority given to the fight against malaria in the New Partnership for Africa's Development, and encouraged cooperation between members of the World Health Organization, the United Nations system, the Bretton Woods institutions, the private sector and civil society in enhancing capacity building in global public health and in promoting public health at the country level [Ibid., 2003c]. The 38-page 2005 World Summit Outcome noted child and maternal health in passing, stating that the goals of achieving universal access to reproductive health, reducing maternal mortality, improving maternal health, reducing child mortality, promoting gender equality, combating HIV/AIDS and eradicating poverty by 2015 should be integrated into national development strategies [Ibid., 2005a]. The Doha Declaration on Financing for Development does not mention child and maternal health, though it does commit to continue investments in human capital, including health and education, and to support it through ODA [Ibid., 2009a].

The "Outcome of the Conference on the World Financial and Economic Crisis and Its Impact on Development" document confirmed the need to improve access to health services and to address the negative impacts of the crisis, including increasing infant and child mortality [Ibid., 2009b, pp. 3, 7]. However, it understandably was focused on the crisis' implications for international trade, reform of the international financial and economic system, and actions which would contain the effects of the crisis and improve future global resilience. The healthrelated goals are barely noted.

The High-Level Plenary Meeting of the General Assembly on the Millennium Development Goals, at its 65th session, made an extensive and explicit commitment to accelerate and scale up progress on the three health-related MDGs, strengthening the capacity of national health systems to deliver equitable and quality healthcare services, improving national health governance, strengthening international cooperation, scaling up prevention and vaccination programmes, improving child nutrition and building up strategic partnerships [Ibid., 2010, pp. 18-23].

The results for the three health-related MDGs were higher than predicted compared to the early estimates based on calculations using historical evidence regarding progress in the indicators underlying the MDGs [Clemens, Kenny, Moss, 2004]. Global under-five and maternal mortality declined by more than half between 1990 and 2015, the rate of child mortality reduction tripled, and global measles vaccine coverage rose from $73 \%$ in 2000 to $84 \%$ in 2013 [UN, 2015c, p. 5]. A tenfold increase in international financing for malaria helped cut the incidence of global malaria by $37 \%$ and mortality by $58 \%$ [Ibid., p. 47]. Tuberculosis incidence, mortality and infections were reduced by $50 \%$. Progress was notable, though profound disparities remained between regions, countries, and urban and rural populations. Obviously the positive dynamics were the result of a combination of efforts aimed at poverty eradication, enhancing literacy, building health systems' capacities and increased access to clean water, sanitation, and improved housing conditions. These outcomes confirm that the analytical assumptions regarding the role of income and education in achieving health goals [Filmer, Pritchett, 2000] were correct and the comprehensive pursuit of MDGs 1-6 proved effective. 


\section{Environmental Sustainability}

The World Summit on Sustainable Development, held in Johannesburg, South Africa, from 26 August - 4 September 2002, proclaimed "sustainable development as a key element of the overarching framework for United Nations activities, in particular for achieving the internationally agreed development goals, including those contained in the United Nations Millennium Declaration." The World Summit Political Declaration and the Johannesburg Plan of Implementation were endorsed by a resolution of the GA [UN, 2003d, Para. 3]. Despite "continuing resistance at government level to integrating the social, environmental and economic dimensions across government departments" [Doran, 2002, p. 14], as a result of the summit the understanding of sustainable development was broadened and strengthened, particularly the important linkages between poverty, the environment and the use of natural resources [Ibid., 2002, p. 17].

The Plan of Action elaborated the MDGs on poverty eradication, education and health; expanded the targets on environmental sustainability; called for an increased commitment on ODA, strengthened institutional frameworks, and enhanced partnership for sustainable development [UN, 2002d]. The GA annually reviewed the implementation of the World Summit on Sustainable Development, the Johannesburg Action Plan, and the Programme for the Further Implementation of Agenda 21 [Ibid., 2004b]. The main commitments agreed in the Plan of Implementation, including actions for countries with special needs and regional initiatives, were consistently followed up to keep momentum.

The 2005 World Summit definitively confirmed that "sustainable development in its economic, social and environmental aspects constitutes a key element of the overarching framework of United Nations activities" [Ibid., 2005a, Para. 11]. It committed to integrate the three components of sustainable development - economic development, social development and environmental protection - as interdependent and mutually reinforcing pillars [Ibid., 2005a, Para. 48], and reiterated the priority of strengthening global partnership and international cooperation for sustainable development.

Building capacity for sustainable development requires resources. The global financial and economic crisis dealt a severe blow to mobilization of domestic and international finance for development, and exacerbated external debt problems and the inequalities in access to trade, finance, investment, and sustainable infrastructure. It also setback economic growth, and put at risk the achievement of the MDGs. Further, it made it hard to choose between more economic output or more environmental protection, especially for developing countries.

In the aftermath of the crisis, the Doha Declaration on Financing for Development outlined a list of priority actions to contain the effects of the crisis. It resolved to address systemic issues and to enhance the coherence and consistency of the international monetary, financial and trading systems in support of development. Despite the pressures of the crisis, the outcome document managed to keep sustainable development as a focus. It reaffirmed the principles of sustainable development and underscored "the need for a global consensus on the key values and principles that will promote sustainable, fair and equitable economic development" [Ibid., 2009b, Para. 41]. It also encouraged "the utilization of national stimulus packages, for those countries in a position to do so, to contribute to sustainable development, sustainable longterm growth, promotion of full and productive employment and decent work for all and poverty eradication" [Ibid., 2009b, Para. 32]. However, the subsequent pattern of cooperation and resolutions on sustainable development, and the narrative set forth by the Johannesburg Plan, did not change.

By 2015 the target of halving the proportion of population without access to safe drinking water was surpassed and access to improved sanitation increased from $54 \%$ to $68 \%$. However, 
water scarcity affected more than $40 \%$ of people and was projected to increase; inequalities between regions, and between rural and urban populations remained high; global carbon dioxide emissions accelerated, increasing by over 50\% compared to 1990 [UN, 2015c, pp. 52-61]. The Millennium Development Goals Report advocated a true integration of environmental, social and economic dimensions in the post-2015 agenda.

\section{Partnership for Attaining the MDGs (MDG 8)}

The global partnership for development was "the only MDG which addressed the responsibility of wealthier countries to assist poorer states in meeting their development and human rights commitments. Though it covered a wide range of transnational policy issues, including trade, aid and debt, it was the only goal that placed no concrete quantitative targets to reach by 2015" [Center for Economic and Social Rights, n. d.]. It sought to promote changes at the global level, which the international community had not been able to achieve in the four UN development decades [Larionova, Safonkina, 2018]. MDG 8 committed to develop an open, predictable, rule-based, non-discriminatory trading and economic system; to deal exhaustively with the debt problems of developing nations; to address the special needs of the least-developed, small island, and landlocked developing countries; and to provide access to affordable essential drugs and avail the benefits of new technologies in the developing world. These targets are a far cry from the reform of the international economic system implied by MDG 8, which had been included to gain support of the developing countries.

MDG 8 was not able to re-energize the promotion of a democratic and equitable international order [UN, 2001b], a credible multilateral trading system [Ibid., 2001c], or a strong and stable international financial architecture [Ibid., 2001d] - key conditions if globalization is to work for all. The gap between the narrative in the GA and cooperation with IOs remained wide. In debate on the international financial architecture, the U.S. invariably reiterated its longstanding position that "it is essential that the full independence of the international financial institutions be completely respected and upheld, especially in ... such areas of concern as the suggestion of regulatory frameworks for short-term capital flows and trade in currencies, as well as the consideration of the consolidation of a broader global agenda regarding the international financial system" [Ibid., 2000b]. Though the resolutions on "A Strengthened and Stable International Financial Architecture Responsive to the Priorities of Growth and Development, Especially in Developing Countries, and to the Promotion of Economic and Social Equity" [Ibid., 2002c] and "Enhancing International Cooperation Towards a Durable Solution to the External Debt Problems of Developing Countries" [Ibid., 2002f] were adopted at each session they did little to promote reform or relieve the debt burden.

The GA's calls “upon members of the World Trade Organization to engage in negotiations with a renewed sense of urgency and purpose and to redouble their efforts to achieve a successful outcome of the Doha work programme, including on the issues of particular interest to the developing countries" [Ibid., 2004c] did not advance the Doha negotiations "towards the successful, timely and development-oriented conclusion" [Ibid., 2004d].

The GA sought to harness support of a wide range of stakeholders - the donors, bodies of the United Nations system, international financial institutions and other multilateral organizations, business and NGOs - for implementation of the Programme of Action for the Least Developed Countries [Ibid., 2009f], the Programme of Action for the Sustainable Development of Small Island Developing States [Ibid., 2008], and the Almaty Programme of Action: Addressing the Special Needs of Landlocked Developing Countries [Ibid., 2004e]. To advance a global partnership, the GA sought to define modalities for enhanced cooperation between the United Nations and all relevant partners in the annual resolutions on global partnership [Ibid., 2002e], initiated the 
High-Level Dialogue on Strengthening International Economic Cooperation for Development Through Partnership [UN, 2003e], and endeavoured to consolidate the UN's central role in promoting international cooperation for development [Ibid., 2005d] in the context of globalization.

By the time of the 2005 World Summit, little progress was made on MDG 8, especially on the systemic issues. The smooth language of the outcome document [Ibid., 2005a] on commitments to the global partnership for development, substantial increases in official development, greater foreign direct investment in developing countries, a timely, effective, comprehensive and durable solution to the debt problems of developing countries through debt relief, a universal, rule-based, open, non-discriminatory and equitable multilateral trading system, reform of the international financial architecture to enhance the voice and participation of developing countries and countries with economies in transition in the Bretton Woods institutions, as well as the goal of sustainable development, concealed tough divisions among the member states. The deep disappointments were openly stated by the representative of Cuba, a country with little to lose by alienating the document's sponsors [Ibid., 2005b, p. 46] ${ }^{3}$ given that the U.S. insisted on its sovereign right to use unilateral economic sanctions as an influential diplomatic tool to achieve legitimate foreign policy objectives [Ibid., 2005c] and had voted against UN resolutions on unilateral economic measures as a means of political and economic coercion [Ibid., 2006] at each session. Criticisms of the document included the absence of concrete steps to meet the MDGs, the last-minute submission of 750 amendments which jeopardized the summit, the enormous pressure by the U.S. and its allies to include the concepts of responsibility to protect and human security, the presentation of debt cancellation as official development assistance, and the absence of concrete commitments to work toward a new international order that is more just and equitable [Ibid., 2005b, p. 47]. In his solemn conclusion of the debate the co-chair had to diplomatically acknowledge that "the political message that emerged from our debate is clear: we need to redouble our efforts" [Ibid., 2005b, p. 48].

The 2008 financial crisis and subsequent global economic slowdown severely affected progress on the MDGs and demonstrated clearly how far the world was from the goal of achieving an equitable and inclusive international economic order [Ibid., 2009c] which the UN had sought to achieve for decades. The GA committed to consolidate global partnership, work on a coordinated and comprehensive global response to the crisis, and address its immediate impact and causes. However, the commitment did not provide the required catalytic influence for either the consolidation of a global partnership or the transition to a more inclusive, equitable, balanced, and development-oriented economic system.

The outcome document of the UN Conference on the World Financial and Economic Crisis and Its Impact on Development proposed a comprehensive set of actions, many of which were aligned with the decisions made at the Washington and London G20 summits. It is not accidental that the UN conference outcome document explicitly supported commitments the G20 leaders made at the London meeting [Ibid., 2009d, Para. 19, 28]. These included fiscal stimulus if national circumstances permitted, resistance to protectionism, improving regulation, and reform of international financial and economic governance. The GA requested the Economic and Social Council to "Consider and make recommendations to the UN regarding the possible establishment of an ad hoc panel of experts on the world economic and financial crisis and its impact on development" [Ibid., 2009d, Para. 56(e)].

However, the outcome document did not reflect the much more ambitious recommendations of the Commission of Experts on Reform of the International Financial and Monetary System, convened by the UN GA president under the leadership of Chairman Joseph Stiglitz. Inter

${ }^{3}$ The U.S. supported the 2005 World Summit Outcome document. See the statement of Mr. Bolton, the U.S. representative in the debate. 
alia, the Commission recommended the "establishment of the Global Economic Coordination Council at a level equivalent with the UN GA and the SC with a mandate to assess developments and provide leadership on economic issues that require global action while taking into account social and ecological factors" [UN, 2009e, p. 91]. The Commission proposed that "The Council would have a mandate over the UN System in the economic, social, and environmental fields, which include the Bretton Woods Institutions (BWIs) and should include the WTO by bringing it formally into the UN System, and not only over the UN and its Funds and Programs, as has been characteristic of ECOSOC (which will thus continue exercising its traditional functions). Representation could be based on a constituency system designed to ensure that all continents and all major economies are represented. At the same time, its size should be guided by the fact that the Council must remain small enough for effective discussion and decision-making. In addition, active participation by and consultation with other important institutions, such as the World Bank, IMF, ILO, WTO, and of course the UN Secretariat, would be crucial" [Ibid., 2009e, p. 91].

The Commission's vision of economic governance reform was met with strong opposition by the western countries. The objection to using the UN to coordinate or lead on international economic issues was forcefully expressed by the U.S.: "Our strong view is that the UN does not have the expertise or the mandate to serve as a forum for meaningful dialogue or to provide direction on issues such as reserve systems, the international financial institutions and the international financial architecture" [Buxton, 2011, p. 308].

As R. Wade [2012] notes, "The western states, led by the U.S. and UK, wanted the G20 and the IMF, in which they have much more influence, to take charge of a global response. The U.S. ambassador to the UN, Susan Rice, and her staff made it clear that the U.S. government thought the G20, not the General Assembly, should be the central forum for debate. The UK wished to boost global leadership role of the UK Prime Minister, Gordon Brown, and did most to restrict the Commission's work. Its ambassador to the UN, John Sawers, was hostile to the project, and orchestrated phone calls from the British diplomatic service to nearly all members of the commission telling them they should quit to avoid personal and professional embarrassment. Coordinated by the U.S. and UK the opposition worked to ensure a dismissive coverage in the press and squashed the UN follow up on the conference decisions [Wade, 2012]. The IMF reassumed and the G20 assumed the role of key legitimate fora for negotiations on global economic governance." The leading western states failed to engage constructively with the UN to forge a truly collective response to the unprecedented economic and financial crisis. Though many of the Commission's recommendations were recognized by G20 decisions, the reform of global economic governance is unfulfilled and the root causes of the crisis have not been eradicated. The UN's efforts to coordinate a concerted response to the crisis and a transition to a more inclusive, equitable, balanced, development-oriented and sustainable economic development [UN, 2010] were rebuffed.

Thus, progress on the partnership for development targets was mixed. ODA increased by $66 \%$ between 2000 and 2014 [Ibid., 2015c, pp. 62-3], and OECD data shows that ODA rose very modestly after 2009 with serious setbacks in private flows.

Imports from the developing countries increased, with $84 \%$ of imports from the leastdeveloped countries (LDCs) and 79\% from developing countries admitted duty free in 2014. The proportion of external debt service to exports revenue fell from $12 \%$ in 2000 to $3 \%$ in 2013. Though Internet penetration grew from 6\% of the world's population in 2000 to $43 \%$ in 2015 and the number of mobile phone subscriptions increased tenfold, from 738 million in 2000 to over 7 billion in 2015, the digital divide remained wide. Only one third of the population in developing countries had access to the Internet, compared with $82 \%$ in developed countries. With $97 \%$ global mobile penetration in 2015, it reached only $64 \%$ in the LDCs [Ibid., 2015c, 
pp. 64-8]. However, very little progress was made on the target of developing an open, predictable, rule-based, non-discriminatory trading and economic system.

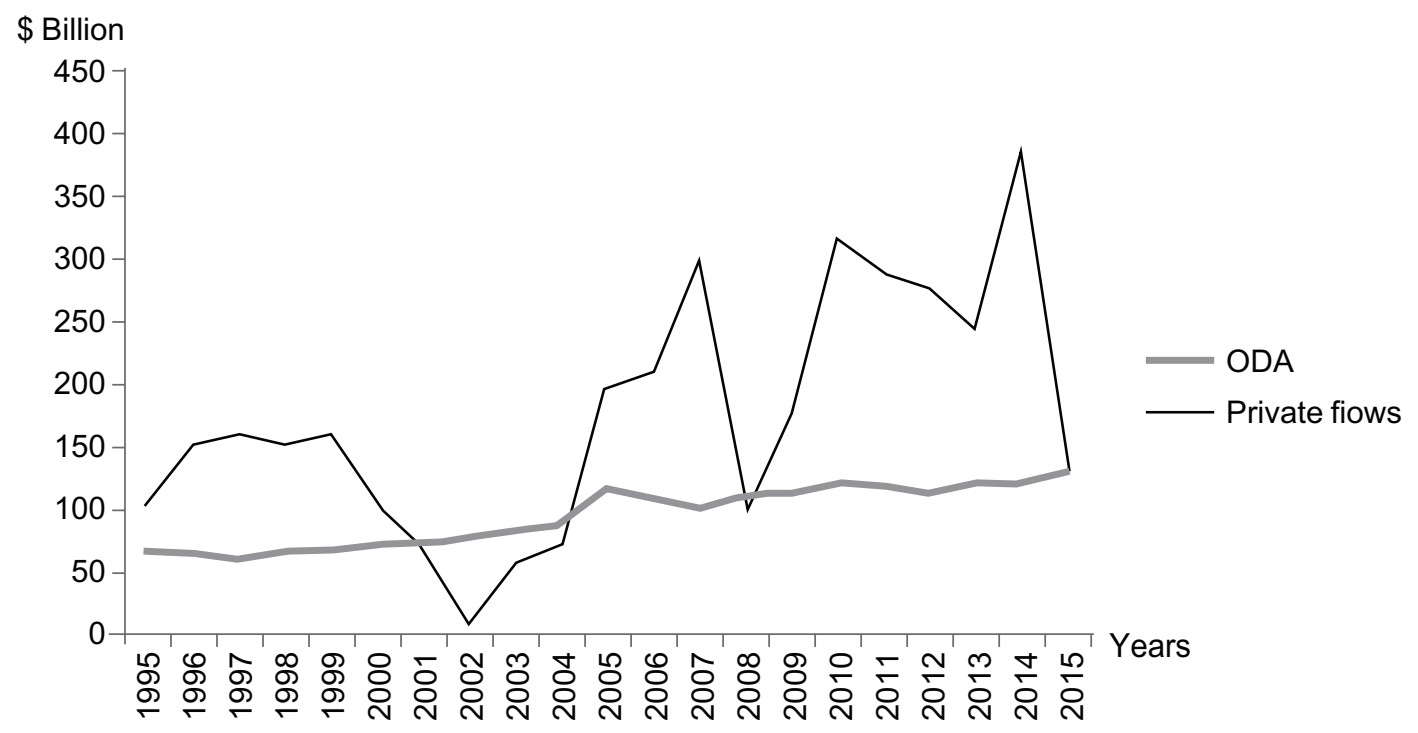

Fig. 1. ODA and Private Flows

Source: [DAC-OECD, XXXX - not in references - the only DAC document listed is 1996, which predates much of the data in this figure].

The Addis Ababa Action Agenda called for an enhanced and revitalized global partnership as a vehicle for strengthening international cooperation for the implementation of the post-2015 development agenda [UN, 2015a, Para. 10]. The 2030 Agenda for Sustainable Development inherited the goal of revitalizing the Global Partnership for Sustainable Development. It includes attainment of a universal, rules-based, open, non-discriminatory and equitable multilateral trading system among the 19 targets of SDG 17, while reform of the economic and finance system is explicitly absent from the list [Ibid., 2015b, pp. 26-7].

\section{Conclusion}

The MDGs put forward an ambitious agenda for reducing poverty and improving lives. They are sometimes discarded as a bureaucratic exercise which made little impact on reality, with progress on development outcomes being seen simply as a product of underlying economic growth rather than directed policy efforts. However, quantitative assessments which calculated rates of progress from the pre-MDG period to establish business-as-usual trajectories and compared these with rates of progress following the establishment of the MDGs revealed an acceleration in progress compared with the pre-MDG reference period [McArthur, Rasmussen, 2017, p. ii]. The MDGs and the UN's endeavours to deliver on the promise to reduce poverty made a difference to the world. Though the progress was uneven, the calculations showed that "all regions except East Asia and the Pacific had accelerated gains in headcount poverty ratios declines after the MDGs were established. When excluding China and India from the equation, the rest of the developing world likely cut extreme poverty from approximately $32 \%$ in 1991 to $15 \%$ in 2013... On global health outcomes, the MDG era might have been the most successful 
period in history... primary school completion rates and gender parity in primary education accelerated in a majority of relevant countries... The clearest shortcomings during the MDG era were in the realm of environmental sustainability" [McArthur, Rasmussen, 2017, p. 45]. The greatest disappointment was a lack of progress on MDG 8, most markedly, on addressing systemic issues of global economic governance.

As in past decades, in the MDG era the UN was not able to challenge the existing power structure in a significant way. "They could discuss trade reform and debt relief in terms of changes and improvements, but not in terms of any fundamental changes to the overarching system. Such matters were for other fora - WTO, G7/G8 the OECD - in which the US, and other powerful entities, the EU, China and India would flex their muscles. All of these could be ambivalent about Goals 1 to 6 of the MDGs, but would keep a careful eye on issues such as trade, global environmental change and redesigning the international financial architecture" [Hulme, 2009, p. 45].

The MDGs played an epistemic role, providing a cognitive reference point for a wide range of stakeholders to organize the collaboration, the actions and the data in relation to the commonly agreed goals and targets. They played a motivational role focusing and incentivizing cooperation. As imperfect as these eight goals and their 21 targets may have been, they gave all partners objectives against which progress could be judged [Abdel-Malek, 2015, p. 12]. The goals became a focus of coordination between the actors, thus playing a coordinating role. And even if progress in building a global partnership was modest, "adoption of the MDGs, a new model, in which governments, businesses, investors, and all civil society groups form 'multistakeholder' partnerships to solve global problems has gained currency, both discursively and materially. ... The UN invested heavily in these partnerships to bring in corporations and philanthropic foundations" [Kvangraven, Reddy, 2015, p. 16].

The UN tried to steer cooperation in pursuit of the MDGs despite vested interests, discord among the key stakeholders, setbacks caused by the global economic crisis and subsequent downturn, systemic imbalances, and persistent fragilities.

Though the MDGs failed to deliver on MDG 8's key target of developing an open, predictable, rule-based, and non-discriminatory trading and economic system, they built a foundation and provided important lessons for cooperation to achieve their successor - the SDGs. The lessons should be learnt. Success in achieving the SDGs depends on providing the global governance architecture for the 21 st century promised by the G20 and the UN. One of the crucial goals is attaining SDG 17's target of promoting a universal, rules-based, open, nondiscriminatory, equitable trading system under the WTO, including through the conclusion of negotiations under its Doha Development Agenda, which is currently deadlocked and which amounts to much more than the indicator of the world-weighted tariff-average. The other key success factor is explicitly absent from the list of SDG targets: reform of the international monetary and financial system to equitably reflect the role of the emerging markets and developing countries, address vulnerabilities stemming from increasing prominence of the dollar in trade invoicing and in global banking and finance, ${ }^{4}$ and provide a foundation for inclusive and sustainable development. Inability to achieve these targets was a key challenge for implementing

${ }^{4}$ Trade invoicing and its increasing prominence in global banking and finance increase spillover effects from developments in the U.S. economy and weakens the other countries' monetary policies effects. Growth in dollar denominated borrowings increases vulnerabilities to the dollar exchange rate and causes central banks governors to continue building costly dollar reserves. Transition to a new hegemonic reserve currency like the Renminbi would reduce the influence of the U.S. on the global financial cycle. The dollar's influence on global financial conditions could similarly decline if a financial architecture developed around the Synthetic Hegemonic Currency (SHC). Ultimately, a multipolar global economy requires a new international monetary system to realize its full potential [Carney, 2019]. 
the MDGs, and these targets remain key challenges for the SDGs' implementation. Ultimately, the SDGs require a truly global partnership able to build a new economic order.

\section{References}

Actions and Future Prospects. Studies No 88 / German Development Institute. Available at: https://www. diegdi.de/uploads/media/Studies_88.pdf (accessed 21 May 2019).

Buxton N. (2011) The Invisible Summit: The UN Conference on Global Economic Crisis: An Eyewitness Account. Globalization in Crisis (B.K. Gills (ed.)). Routledge.

Caliari A. (2013) Analysis of Millennium Development Goal 8: A Global Partnership for Development. The Power of Numbers: A Critical Review of MDG Targets for Human Development and Human Rights: Working Papers Series (May 2013). Available at: https://www.dawnnet.org/sites/default/files/articles/ caliariobjetivo_8_a_global_partnership_for_development.pdf (accessed 23 January 2020).

Carney M. (2019) The Growing Challenges for Monetary Policy in the Current International Monetary and Financial System. Speech Given by Mark Carney, Governor of the Bank of England, at the Jackson Hole Symposium, 23 August. Available at: https://www.bankofengland.co.uk/-/media/boe/files/speech/2019/thegrowing-challenges-for-monetary-policy-speech-by-mark-carney.pdf?la=en\&hash=01A18270247C456901D 4043F59D4B79F09B6BFBC (accessed 23 January 2020).

Center for Economic and Social Rights (n. d.). Building a Global Partnership for Development Through MDG 8. Available at: http://cesr.org/building-global-partnership-development-through-mdg-8 (accessed 21 May 2019).

Clemens M., Kenney C., Moss T. (2004) The Trouble With the MDGs: Confronting Expectations of Aid and Development Success. Working Paper No 40 / Center for Global Development. Available at: https://www. cgdev.org/sites/default/files/2749_file_cgd_wp040Rev3_1.pdf (accessed 21 May 2019).

Doran P. (2002) World Summit on Sustainable Development (Johannesburg): An Assessment for IISD. Briefing Paper. Available at: https://www.iisd.org/pdf/2002/wssd_assessment.pdf (accessed 21 May 2019).

Fehling M., Nelson B.D., Venkatapuram D. (2013) Limitations of the Millennium Development Goas: A Literature Review. Global Public Health, vol. 8, no 10, pp. 1109-22. Available at: https://doi.org/10.1080/174416 92.2013.845676.

Filmer D., Pritchett L. (2000) The Impact of Public Spending on Health: Does Money Matter? Social Science \& Medicine, vol 49, no 10, pp. 1309-23. Available at: https://doi.org/10.1016/S0277-9536(99)00150-1 (accessed 21 May 2019).

Hulme D. (2009) The Millennium Development Goals (MDGs): A Short History of the World's Biggest Promise. BWPI Working Paper No 100 / Brooks World Poverty Institute. Available at http://dx.doi.org/10.2139/ ssrn.1544271.

International Monetary Fund (IMF) (2019). World Economic Outlook, Growth Slow Down, Precarious Recovery. World Economic Outlook Reports. Available at: https://www.imf.org/en/Publications/WEO/Issues/2019/03/28/world-economic-outlook-april-2019 (accessed 16 May 2019).

Kvangraven I.H., Reddy S. (2015) Global Development Goals: If at All, Why, When and How? Working Paper 23/2015 / The New School for Social Research. Available at: https://doi.org/10.13140/RG.2.1.1911.6243 (accessed 16 May 2019).

Landford M. (2016) Lost in Transformation? The Politics of the Sustainable Development Goals. Ethics \& International Affairs, vol. 30, no 2, pp. 167-76. Available at: https://www.jus.uio.no/ior/english/people/aca/ malcolml/sdgs-politics-langford.pdf (accessed 16 May 2019).

Larionova M., Safonkina E. (2018) The First Five Decades of Cooperation for Development: Actors, Achievements and Challenges. International Organisations Research Journal, vol. 13, no 4, pp. 96-121. Available at: https://iorj.hse.ru/data/2019/02/07/1204070250/M.\%20Larionova,\%20E.\%20Safonkina.pdf (accessed 16 May 2019). 
McArthur W.J., Rasmussen K. (2017) Change of Pace: Accelerations and Advances During the Millennium Development Goal Era. Global Economy \& Development Working Paper 98, Brookings. Available at: https:// www.brookings.edu/wp-content/uploads/2017/01/global_20170111_change_of_pace.pdf (accessed 21 May 2019).

Organisation for Economic Co-operation and Development (OECD) (1996). Shaping the 21st Century: The Contribution of Development Co-operation. Development Assistance Committee (DAC). Available at: https://www.oecd.org/dac/2508761.pdf (accessed 16 May 2019).

United Nations (UN) (1979). Global Negotiations Relating to International Economic Co-operation for Development. General Assembly Resolution A/RES/34/138. Available at: https://undocs.org/en/A/ RES/34/138 (accessed 16 May 2019).

United Nations (UN) (2000a). The Dakar Framework for Action: Education for All: Meeting Our Collective Commitments (Including Six Regional Frameworks for Action). Available at: https://unesdoc.unesco.org/ ark:/48223/pf0000121147 (accessed 21 May 2019).

United Nations (UN) (2000b). Official Records of the General Assembly, Eight-Seventh Plenary. Available at: https://www.un.org/en/ga/search/view_doc.asp?symbol=A/55/PV.87 (accessed 21 May 2019).

United Nations (UN) (2001a). Road Map Towards the Implementation of the United Nations Millennium Declaration. Available at: https://www.un.org/millenniumgoals/sgreport2001.pdf (accessed 16 May 2019).

United Nations (UN) (2001b). Promotion of a Democratic and Equitable International Order. General Assembly Resolution A/RES/55/107. Available at: https://www.un.org/en/ga/search/view_doc.asp?symbol=A/ RES/55/107 (accessed 21 May 2019).

United Nations (UN) (2001c). International Trade and Development. General Assembly Resolution A/ RES/55/182. Available at: https://www.un.org/en/ga/search/view_doc.asp?symbol=A/RES/55/182 (accessed 21 May 2019).

United Nations (UN) (2001d). Towards a Strengthened and Stable International Financial Architecture Responsive to the Priorities of Growth and Development, Especially in Developing Countries, and to the Promotion of Economic and Social Equity. General Assembly Resolution A/RES/55/186. Available at: https://www. un.org/en/ga/search/view_doc.asp?symbol=A/RES/55/186 (accessed 21 May 2019).

United Nations (UN) (2002a). Implementation of the First United Nations Decade for the Eradication of Poverty (1997-2006), Including the Proposal to Establish a World Solidarity Fund for Poverty Eradication. General Assembly Resolution A/RES/56/207. Available at: https://www.un.org/en/ga/search/view_doc. asp?symbol=A/RES/56/207 (accessed 16 May 2019).

United Nations (UN) (2002b). United Nations Literacy Decade: Education for All. General Assembly Resolution A/RES/57/166. Available at: https://www.un.org/en/ga/search/view_doc.asp?symbol=A/RES/56/116 (accessed 21 May 2019).

United Nations (UN) (2002c). Towards a Strengthened and Stable International Financial Architecture Responsive to the Priorities of Growth and Development, Especially in Developing Countries, and to the Promotion of Economic and Social Equity. General Assembly Resolution A/RES/58. Available at: https://www. un.org/en/ga/search/view_doc.asp?symbol=A/RES/56/181 (accessed 21 May 2019).

United Nations (2002d). Johannesburg Plan of Action. Available at: http://wedocs.unep.org/bitstream/handle/20.500.11822/19097/Johannesburg_Plan_of_Action.pdf?sequence=1\&isAllowed=y (accessed 21 May 2019).

United Nations (UN) (2002e). Towards Global Partnership. General Assembly Resolution A/RES/56/76. Available at: https://www.un.org/en/ga/search/view_doc.asp?symbol=A/RES/56/76 (accessed 21 May 2019).

United Nations (UN) (2002f). Enhancing International Cooperation Towards a Durable Solution to the External Debt Problems of Developing Countries. General Assembly Resolution A/RES/56/184. Available at: https://www.un.org/en/ga/search/view_doc.asp?symbol=A/RES/56/184 (accessed 21 May 2019).

United Nations (UN) (2002g). Report of the International Conference on Financing for Development. Available at: https://www.globalpolicy.org/images/pdfs/monterreyreport.pdf (accessed 16 May 2019).

United Nations (UN) (2003a). United Nations Literacy Decade: Education for All. Available at: https://www. un.org/en/ga/search/view_doc.asp?symbol=A/RES/57/166 (accessed 21 May 2019). 
United Nations (UN) (2003b). 2001-2010: Decade to Roll Back Malaria in Developing Countries, Particularly in Africa. General Assembly Resolution A/RES/57/294. Available at: https://www.un.org/en/ga/search/ view_doc.asp?symbol=A/RES/57/294 (accessed 21 May 2019).

United Nations (UN) (2003c). Enhancing Capacity-Building in Global Public Health. General Assembly Resolution A/RES/58/3. Available at: https://www.un.org/en/ga/search/view_doc.asp?symbol=A/RES/58/3 (accessed 21 May 2019).

United Nations (UN) (2003d). World Summit on Sustainable Development. General Assembly Resolution A/ RES/57/253. Available at: https:// https://www.un.org/en/ga/search/view_doc.asp?symbol=A/RES/57/253 (accessed 21 May 2019).

United Nations (UN) (2003e). High-Level Dialogue on Strengthening International Economic Cooperation for Development Through Partnership. General Assembly Resolution A/RES/57/250. Available at: https:// www.un.org/en/ga/search/view_doc.asp?symbol=A/RES/57/250 (accessed 21 May 2019).

United Nations (UN) (2004a). Implementation of the First United Nations Decade for the Eradication of Poverty (1997-2006). General Assembly Resolution A/RES/58/222. Available at: https://www.un.org/en/ga/ search/view_doc.asp?symbol=A/RES/58/222 (16 May 2019).

United Nations (UN) (2004b). Implementation of Agenda 21, the Programme for the Further Implementation of Agenda 21 and the Outcomes of the World Summit on Sustainable Development. General Assembly Resolution A/RES/58/218. Available at: https://www.un.org/en/ga/search/view_doc.asp?symbol=A/RES/58/218 (accessed 21 May 2019).

United Nations (UN) (2004c). International Trade and Development. General Assembly Resolution A/ RES/58/197. Available at: https://www.un.org/en/ga/search/view_doc.asp?symbol=A/RES/58/197 (accessed 21 May 2019).

United Nations (UN) (2004d). Role of the United Nations in Promoting Development in the Context of Globalization and Interdependence. General Assembly Resolution A/RES/58/225. Available at: https://www. un.org/en/ga/search/view_doc.asp?symbol=A/RES/58/225 (accessed 21 May 2019).

United Nations (UN) (2004e). Almaty Programme of Action: Addressing the Special Needs of Landlocked Developing Countries within a New Global Framework for Transit Transport Cooperation for Landlocked and Transit Developing Countries. General Assembly Resolution A/RES/58/201. Available at: https://www. un.org/en/ga/search/view_doc.asp?symbol=A/RES/58/201 (accessed 21 May 2019).

United Nations (UN) (2005a). 2005 World Summit Outcome. General Assembly Resolution A/RES/60/1. Available at: https://www.un.org/en/ga/search/view_doc.asp?symbol=A/RES/60/1 (accessed 21 May 2019).

United Nations (UN) (2005b). Official Records of the General Assembly, Eighth Plenary. Available at: https:// www.un.org/en/ga/search/view_doc.asp?symbol=A/60/PV.8 (accessed 21 May 2019).

United Nations (UN) (2005c). Official Records of the General Assembly, Sixty-Eighth Plenary Meeting. General Assembly Resolution A/60/PV.68. Available at: https://www.un.org/en/ga/search/view_doc. asp?symbol=A/60/PV.68 (accessed 21 May 2019).

United Nations (UN) (2005d). Role of the United Nations in Promoting Development in the Context of Globalization and Interdependence. General Assembly Resolution A/RES/59/240. Available at: https://www. un.org/en/ga/search/view_doc.asp?symbol=A/RES/59/240 (accessed 21 May 2019).

United Nations (UN) (2006). Unilateral Economic Measures as a Means of Political and Economic Coercion Against Developing Countries. General Assembly Resolution A/RES/60/185. Available at: https://www. un.org/en/ga/search/view_doc.asp?symbol=A/RES/60/185 (accessed 21 May 2019).

United Nations (UN) (2008). Follow-Up to and Implementation of the Mauritius Strategy for the Further Implementation of the Programme of Action for the Sustainable Development of Small Island Developing States. General Assembly Resolution A/RES/62/191. Available at: https://www.un.org/en/ga/search/viewdoc. asp?symbol=A/RES/62/191 (accessed 21 May 2019).

United Nations (UN) (2009a). Doha Declaration on Financing for Development: Outcome Document of the Follow-Up International Conference on Financing for Development to Review the Implementation of the Monterrey Consensus. General Assembly Resolution A/RES/63/239. Available at: https://www.un.org/en/ga/ search/view_doc.asp?symbol=A/RES/63/239 (accessed 21 May 2019). 
United Nations (UN) (2009b). Outcome of the Conference on the World Financial and Economic Crisis and Its Impact on Development. General Assembly Resolution A/RES/63/303. Available at: https://www.un.org/ en/ga/search/view_doc.asp?symbol=A/RES/63/303 (accessed 21 May 2019).

United Nations (UN) (2009c). Towards a New International Economic Order. General Assembly Resolution A/RES/63/224. Available at: https://www.un.org/en/ga/search/view_doc.asp?symbol=A/RES/63/224 (accessed 21 May 2019).

United Nations (UN) (2009d). Outcome of the Conference on the World Financial and Economic Crisis and Its Impact on Development. General Assembly Resolution A/RES/63/303. Available at: https://www.un.org/ en/ga/search/view_doc.asp?symbol=A/RES/63/303 (accessed 21 May 2019).

United Nations (UN) (2009e). Report of the Commission of Experts of the President of the United Nations General Assembly on Reforms of the International Monetary and Financial System. Available at: https://digitallibrary.un.org/record/657634 (accessed 23 January 2020).

United Nations (UN) (2009f). Implementation of the Brussels Programme of Action for the Least Developed Countries for the Decade 2001-2010. A/RES/63/227. Available at: https://www.un.org/en/ga/search/ view_doc.asp?symbol=A/RES/63/227 (accessed 21 May 2019).

United Nations (UN) (2010). Keeping the Promise: United to Achieve the Millennium Development Goals. General Assembly Resolution A/RES/65/1. Available at: https://www.un.org/en/ga/search/view_doc. asp?symbol=A/RES/65/1 (accessed 21 May 2019).

United Nations (UN) (2014). Second United Nations Decade for the Eradication of Poverty (2008-2017). General Assembly Resolution A/RES/68/226. Available at: https://www.un.org/en/ga/search/view_doc. asp?symbol=A/RES/68/226 (accessed 16 May 2019).

United Nations (UN) (2015a). Addis Ababa Action Agenda of the Third International Conference on Financing for Development (Addis Ababa Action Agenda). General Assembly Resolution A/RES/69/313. Available at: https://www.un.org/en/ga/search/view_doc.asp?symbol=A/RES/69/313 (accessed 21 May 2019).

United Nations (UN) (2015b). Transforming Our World: The 2030 Agenda for Sustainable Development. General Assembly Resolution A/RES/70/1. Available at: https://www.un.org/en/ga/search/view_doc. asp?symbol=A/RES/70/1 (accessed 21 May 2019).

United Nations (UN) (2015c). The Millennium Development Goals Report. Available at: https://www.un.org/ millenniumgoals/2015_MDG_Report/pdf/MDG\%202015\%20rev\%20(July\%201).pdf (accessed 16 May 2019).

United Nations (UN) (2015d). Education for All 2000-2015: Achievements and Challenges. EFA Global Monitoring Report Summary. Available at: https://unesdoc.unesco.org/ark:/48223/pf0000232565 (accessed 21 May 2019).

Wade R. (2012) The G192 Report. Le Monde Diplomatique. Available at: https://mondediplo.com/2012/08/09un (accessed 21 May 2019). 